\title{
Thinking Historically: A Manifesto of Pragmatic Hermeneutics
}

\section{Citation}

Kloppenberg, James T. 2012. Thinking Historically: A Manifesto of Pragmatic Hermeneutics. Modern Intellectual History 9(1): 201-216.

\section{Published Version}

doi:10.1017/S1479244311000564

\section{Permanent link}

http://nrs.harvard.edu/urn-3:HUL.InstRepos:10718365

\section{Terms of Use}

This article was downloaded from Harvard University's DASH repository, and is made available under the terms and conditions applicable to Open Access Policy Articles, as set forth at http:// nrs.harvard.edu/urn-3:HUL.InstRepos:dash.current.terms-of-use\#OAP

\section{Share Your Story}

The Harvard community has made this article openly available.

Please share how this access benefits you. Submit a story.

Accessibility 
Thinking Historically: A Manifesto of Pragmatic Hermeneutics

James T. Kloppenberg

Harvard University

American intellectual history in the future will be embodied, embedded, and extended. Building on a sturdy foundation of past practices, intellectual historians will consolidate the advances of the last half century and continue to study ideas articulated in multiple registers, by multiple historical actors, for multiple purposes.

Intellectual historians have been studying a widening range of texts through increasingly diverse techniques since the 1960 s, but in practice most of them have deployed the method of pragmatic hermeneutics. That method originated in the late nineteenth- and early twentiethcentury writings of Europeans such as Wilhelm Dilthey, Max Weber, and Jean Jaurès and Americans such as James Harvey Robinson, Charles Beard and Mary Beard, and Carl Becker. Yoking archival research to their understanding that history is written in the present and for the present, these writers shared a commitment to producing history that, no matter how precisely it follows the evidence, inevitably reflects the concerns of the moment. They aimed to reconstruct the past with as much accuracy as possible and to address the needs and aspirations of their contemporary cultures as they understood them. Twenty-first-century inheritors of their legacy will extend both of those commitments by embracing past scholarly practices and incorporating new insights and technologies into historical writing.

Practitioners of hermeneutics see the need to connect parts and wholes, texts and contexts, the past and the present. They shift their focus from the text to the author and back, from the text to its genre and back, from the text to its many historical contexts and back, and from the text to the historian's own experiences and cultural frameworks. They also reject the chimera that historians can shed their skins to achieve timeless understandings of the past and accept the principle that awareness of their own historicity does not absolve historians of the 
responsibility to respect the integrity of the people who preceded them and the sources they left behind. Alert to the irretrievability and foreignness of the past, they see the need to bring the past into the present in order to provide both critical distance on the past and critical depth to the present. Thus the incessant movement of hermeneutics recapitulates the elusive presence of the past in the present and of the present in the past.

Embodied, embedded, and extended. If the overarching orientation of intellectual history is likely to remain as it has been for a century, the particular objects of study and precise techniques of inquiry will continue to evolve. Just as pragmatic hermeneutics uses the figure of hermeneutic circles to express the dynamic movement of the restless historian, so a series of concentric circles helps explain the diverse objects of analysis in intellectual history. Place a particular text at the center, and arrange around it an ever widening set of circles that trace the contexts surrounding any text, whether it is a published work of philosophy or political theory, a diary entry or anonymous pamphlet, an advertisement or a material object, such as a quilt or a sofa, in which numerous cultural currents collide.

Intellectual historians begin at that center, with that text, and work outward toward historical understanding. Different historians will concentrate their energies on different circles as a practical matter of research strategy. Some will study individual thinkers, others philosophical debates, others the texts produced by members of social movements, and others the circulation of ideas among ordinary people. But the broader discursive community of intellectual historians should encompass work in all of those circles, from the most minute to the most expansive. As David Hollinger put it decades ago, intellectual history should remain a commons where multiple discourses meet and mingle. ${ }^{1}$

Embodied. Every text must be studied in relation to its author or authors, particular persons existing in a particular time and place, and interpreted as the embodiment of a particular set of practices and purposes. Ideas, as Vico and Spinoza argued and as intellectual historians understand them in the twenty-first century, never exist in the abstract. Even if we want to 
examine texts in relation to other texts, either earlier, contemporaneous, and later, we must acknowledge that every text came into being through a specific historical process and emerged and survived as a result of the actions of one or more individuals.

For that reason producing new intellectual biographies matters. The Cambridge school originated with the work of Peter Laslett and John Dunn on Locke and matured with Quentin Skinner's and Richard Tuck's detailed studies of Hobbes. American intellectual historians too have shown the value of studying individual writers and their texts. Illustrations are so plentiful that merely listing and discussing the most distinguished examples from recent decades would fill this article. ${ }^{2}$ Ever since Quentin Skinner's path-breaking methodological essays of the 1960s, identifying authorial intent has been among the aims of almost everyone interested in the historical study of ideas; detailed knowledge of the author's life and discursive communities is prerequisite to identifying what she meant to do in a particular text. ${ }^{3}$

Historians no longer study ideas apart from their authors and their multiple contexts. Even as the study of texts includes the physical persons who produced them-the authors whose embodied existence was responsible for the production of the texts being studied-so even those studies extend beyond the focus on individual authors to their interactions with their contemporaries and the complexities of textual interpretation. For decades critics have bashed Arthur Lovejoy's so-called "internalist" study of ideas. That aversion to studying disembodied ideas will and should persist; even Lovejoy himself rarely committed the sins of which he has been accused. He paid much closer attention to situating his "unit ideas" in their historical settings than his critics allege, and he explicitly urged contributors to the Journal of the History of Ideas to locate ideas in contexts. ${ }^{4}$ Even though historians studying texts must interpret them as the work of particular historical persons, bodies in space and time, inhabiting contexts with multiple dimensions, the close analysis of difficult texts will remain an essential component of intellectual history. Textualists of various kinds, ranging from Morton White to Garry Wills, and from Dominick LaCapra to Martin Jay, have demonstrated the fruitfulness of patiently working 
through the difficult, sometimes paradoxical, and often multiple meanings embedded in complex texts. $^{5}$

Scholars associated with the Cambridge School have shown the value of piecing together the discursive communities within which the canonical texts of political theory first appeared. Unless we know what problems individual authors meant to solve, and the conversations in which they took part, we cannot grasp the historical meaning of individual texts. Laslett and Dunn successfully exhumed John Locke's treasonous intent in writing Two Treatises of Government centuries after the texts appeared. Their sleuthing also demonstrated why historians should attend not only to what authors meant to say but also to the myriad ways in which texts can be and have been misread. Readers entirely innocent of authorial intent sometimes project meanings onto texts that can exert a powerful influence demonstrably different from those intended by their authors.

American historians know what meanings can be masked by an overly narrow focus on authors' intentions. Annette Gordon-Reed's path breaking work on the Hemings family has shown that Thomas Jefferson's passionate denunciations of slavery in his Notes on the State of Virginia took on different meanings several times, not only when Jefferson began his relationship with Sally Hemings but also when their children were growing up at Monticello and when understandings of their children's ancestry diverged between white and black communities in the nineteenth century. Other, less volcanic shifts in meaning have also been identified in recent scholarship. James Madison considered himself a friend of democracy, and Woodrow Wilson envisioned both his domestic policy and his plan for a League of Nations as manifestations of the moral philosophy of William James, but neither author's intent was apparent to his contemporaries or to the first few generations of commentators. ${ }^{6}$ Although identifying authors' intended meanings remains an important objective for intellectual historians, it hardly exhausts the range of meanings that matter to historical understanding. 
Not only the embodiment of ideas in persons and historical contexts but awareness of the body itself has become one of the most central preoccupations of intellectual history in recent decades. Whereas scholars studying writers and texts once overlooked questions of race and gender, such considerations have become essential dimensions of intellectual history. The particularity of producers and consumers of texts now includes their physically as well as culturally marked bodies. Inasmuch as the textual evidence will allow access to writers' and readers' emotional lives, the study of the passions-even if no longer likely to be filtered through Freudian lenses-will remain a dimension of intellectual history worth scholars' attention. ${ }^{7}$

Embedded. The meanings of historical texts, even when those meanings are specifically restricted to particular times and discursive communities, remain problematical. The distinction I am drawing between embodiment and embeddedness should thus be understood as a heuristic device, the first calling attention to the physical bodies of individuals, the second to the multiple forms of embeddedness that interest historians who examine ideas. Studies of reception, reader response, and the multiple meanings of complex texts have shown that identifying the precise historical meanings of texts is very hard work. The history of the book, originating in France and quickly imported to America, has enriched and complicated intellectual historians' understanding of the role of ideas in history. Controversies over the relative significance of familiar Enlightenment authors and the clandestine literature of mid-eighteenth-century France have illuminated the difficulty in pinning down the precise meanings readers took from the materials they read. ${ }^{8}$

American history no less than French history has been transformed by the history of the book. Bernard Bailyn's seminal Ideological Origins of the American Revolution acknowledged the importance of long-recognized sources such as the Bible and American religious traditions, the classics, familiar Enlightenment texts from Locke through Rousseau, and English common law. But Bailyn introduced a new element into historians' calculations by looking at the understudied colonial pamphlets inspired by the English dissenting Whig tradition. If the resulting 
squabbles over the relative importance of religious, classical republican, and liberal ideas sometimes veered toward nominalism, spirited investigations of American writers' multiple sources enriched and complicated our historical understanding. The quantitative data gathered by David Lundberg and Henry May underpinned May's argument, in The Enlightenment in America, concerning several distinct forms and stages of Enlightenment. Although many European as well as American historians have tried (and are still trying) to identify a single strand of the Enlightenment as dominant, older works such as Bailyn's and May's remain useful precisely because their emphasis on publishing and reading practices called attention to the diversity and dynamism of the ideas under consideration.

Valuable as these early efforts remain, in recent decades the history of print culture in America has come of age. The publication in 2009 of the fifth and final volume of A History of the Book in America, a multi-author study spearheaded by series editor David D. Hall, brings to completion the first wave of studies paying sustained attention to the production, distribution, circulation, and reception of texts of all kinds. Although the cultural standing of the book itself changed as a result of the technological innovations that occurred during the decades it took to produce this monumental work, these five volumes testify to the transformative effect of focusing on the ways in which texts come to the attention of readers and the multiple ways in which they are read. ${ }^{9}$

Other scholars have looked to other forms of embeddedness in their studies of ideas. By examining five different interpretations of Jonathan Edwards's An Humble Inquiry (1750), David D. Hall convincingly demonstrated Chartier's point about the difficulty historians inevitably encounter in pinning down meanings. ${ }^{10}$ By combing the records of publishers as well as the marginal notations left by one reader of Locke, Eric Slauter has shown the difficulty of

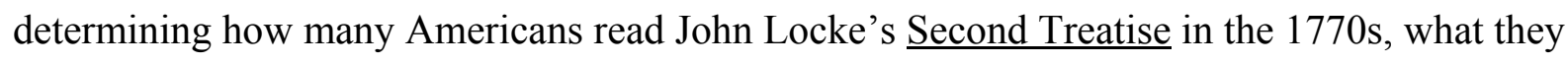
made of it, and has suggested that we acknowledge the role of the Revolution in "making" books instead of assuming that books made the Revolution. ${ }^{11}$ 
Jennifer Ratner-Rosenhagen's forthcoming study American Nietzsche shows how passionately American readers responded to Nietzsche's writings--and just how inconsistent their interpretations were. Showing that the same text can have different effects on different readers, Chartier challenged Darnton's strong reading concerning the subversive force of forbidden books in old regime France. Scholars such as Hall, Slauter, and Hochman have followed in that tradition. Ratner Rosenhagen has fleshed out such objections even more fully by demonstrating, not only from the uses to which American writers put Nietzsche but also from letters written by Americans to Nietzsche's sister, the wildly variable impact of Nietzsche's radical antifoundationalism in America. ${ }^{12}$

A different and equally important form of embeddedness comes into focus when intellectual historians shift their gaze from the diffusion or reception of ideas to the institutional matrix from which texts emerge and the discursive communities of which they become a part. Descended from the union of Karl Mannheim's sociology of knowledge and the work of Pierre Bourdieu, historians operating at the border of science studies have shown how particular disciplinary cultures in the modern academy have shaped scholars' research and reading, writing and teaching. Because such work sometimes risks reducing the meaning of ideas to the circumstances of their production, historians influenced by the more radical strands of science studies should heed the recent advice of Lorraine Daston to pay as much attention to the texts themselves as to the contexts of institutionalization and professionalization. ${ }^{13}$

One further illustration of the embeddedness of intellectual history is the rapid growth of legal history, where ideas and power collide head-on. From the study of the origins of American Constitutionalism to the study of legal theory and institutions to the study of case law, in legal history ideas come together with competing economic, political and social forces. Given the proliferation of joint Ph.D.-J.D. programs in leading universities, such work is likely to become increasingly prominent. 
Extended. American intellectual history will continue to expand in all directions, down and up and across. Many courses taught in mid-twentieth-century American universities bore the name that Arthur Schlesinger, Sr., assigned to his Harvard lecture course, Social and Intellectual History. Most mid-century books in the field, including those by Vernon Louis Parrington, Merle Curti, Henry Steele Commager, and Ralph Henry Gabriel, treated ideas in relation to socio-economic and political history. In the wake of World War II, many American historians joined the national crusade to explain (and often, although not always, to celebrate) the distinctiveness of the newly mature civilization that most Americans credited with having rescued the world from totalitarianism. Many creative minds of that mid-century generation of scholars, including David Potter, Daniel Boorstin, Louis Hartz, Henry Nash Smith, Leo Marx, and Richard Hofstadter, tried to tease the keys to the nation's history from the texts of its most notable writers. Although hardly blind to the tensions in American history, these writers' emphasis on supposedly shared ideas and values fell from favor when but briefly submerged conflicts bubbled back to the surface in the 1960s.

The new social history changed intellectual history forever. No longer could historians blithely characterize ideas or experiences as "American." In the wake of detailed studies devoted to specific towns and communities and particular groups of women and men with distinct ethnoracial and class identities, generalizations would now be hard-won. Despite their champions' crusading spirit, as Ellen Fitzpatrick has shown in History's Memory, such studies marked a return to American historians' practices at the turn of the twentieth century rather than an innovation. But history from the bottom up brought a shift in focus away from elites of all sorts-economic, political, social, and intellectual--and the commitment to studying ordinary people assumed an ideological as well as methodological character.

Within a generation many social historians had shifted their attention from quantitative analysis to interpretations of meaning. That change brought renewed attention to the techniques traditionally employed by intellectual historians, but now that attention was being lavished on 
texts of a different kind: diaries, court records, and the minutes of the meetings of labor unions and organizations devoted to social protest. Some intellectual historians applauded that shift of emphasis, observing with William Bouwsma that "we're all intellectual historians now," but many historians engaged in these studies resisted the embrace and chose to designate themselves cultural historians.

The tendency to use the methods of intellectual history to explore the thought worlds of Americans whom many erstwhile social historians refuse to characterize as "intellectuals" will surely accelerate in the coming decades. A rising generation of scholars will continue to probe an increasingly eclectic array of sources to answer not only questions concerning who did what to whom but what the interaction meant to everybody involved. Whether the results are called intellectual, social, cultural, or political history makes no difference. The proof will be in the writing. ${ }^{14}$

Consider Wendy Wall's recent study Inventing the American Way: The Politics of Consensus from the New Deal to the Civil Rights Movement. Wall draws on the writings of intellectuals such as the journalist Louis Adamic, the anthropologist Margaret Mead, and the Swedish social scientists Alva Myrdal and Gunnar Myrdal. She also uses the records of the Chamber of Commerce, the National Association of Manufacturers, and the CIO. Illuminating the struggle waged over the American future at the end of World War II, Wall demonstrates the strategies conservatives employed to define the "American Way" in terms of competition between free individuals seeking prosperity rather than cooperation among equal communities seeking justice. Is Inventing the American Way an example of intellectual, cultural, political, social, or economic history? Yes.

Intellectual history is already extending into domains often associated with social or cultural history, such as everyday life and the rituals and festivals that punctuate it. Scholars are exploring phenomena as diverse as the history of corporations and the history of jazz, along the way uncovering the ideas that inspired the creators, the critics, and those who became part of the 
nation that proved so hospitable to both American forms of improvisation. The pioneers who created these hybrid cultural forms generated not only new sources of profit and new practices that many scholars have studied, they inspired commentaries, formal and informal, that likewise merit analysis. ${ }^{15}$ In short, as the scope of social history expands to encompass the interpretation of cultural meanings and intellectual history extends from the highly educated to the realm of social protest movements and eventually to the texts produced by bloggers and tweeters, the distinction between social, cultural history, and intellectual history will become increasingly blurred if not entirely erased.

Yet differences of focus and differences of emphasis will inevitably remain, as two recent works on the United States Constitution illustrate. Alison LaCroix's The Intellectual Origins of American Federalism pays close attention to earlier explorations of the idea of federalism stretching from the ancient world to the eighteenth century. Although she never denies the importance of the American experience with town and colonial government as a crucial component in the story, LaCroix concentrates on the development of ideas.

Pauline Maier's Ratification, by contrast, is the most detailed study to date of the debates sparked by the Constitutional Convention. Maier does not delve into Madison's immersion in the writings of Scottish common sense philosophers or earlier thinkers who wrestled with various concepts of federalism, issues that engage LaCroix. Nor does Maier explore the significance of James Wilson's reliance on Rousseau's Social Contract when writing the most influential speeches given in Pennsylvania in the debates over ratification. I consider those issues crucial for understanding both Madison and Wilson. ${ }^{16}$

Yet Maier does provide an admirably careful study of the formal debates in all the state ratifying conventions and the informal wars of words waged in newspapers, pamphlets, and books. Based on the twenty-one volumes of The Documentary History of the Ratification of the

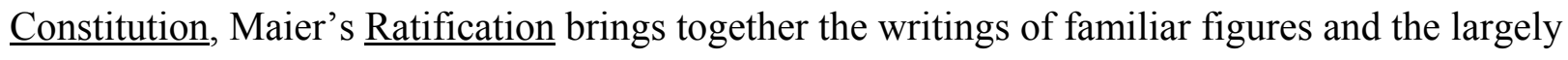
unknown words of ordinary Americans who gathered in town meetings and expressed their ideas 
in local newspapers. Just as Maier had uncovered the sources of Jefferson's Declaration of Independence in American Scripture, illuminating the prototypes written in local, county, and colony-wide assemblies, so in Ratification she examines popular debates over the rules by which the nation would be governed. Is Maier's study an example of intellectual, social, cultural, or political history? Yes.

As intellectual historians extend their reach to meet those social historians working from the bottom up, and vice versa, American historians find themselves returning to one of the field's earliest interests, the history of religion. Samuel Miller's A Brief Retrospect of the Eighteenth

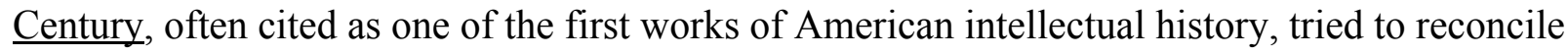
Enlightenment rationalism with his devout Presbyterianism. In the middle of the twentieth century Perry Miller rigorously examined the transformation of Puritan theology. Although his grandest claims for the cultural significance of New England preachers may seem overstated, Miller's commitment to the "life of the mind" helped establish American intellectual history as a distinct field of study.

Now that the long-awaited coming of secularization appears again to have been deferred, this time perhaps indefinitely, scholars are returning to the study of religion in all its forms. Intellectual historians will continue to cover this expansive terrain from the abstractions of theology to the everyday practices of preachers. More detailed studies of religious communities likewise illuminate Americans' animating ideas and ideals, from Jason Maloy’s and David D. Hall's recent studies of the Puritans' political ideas to the explosion of studies on late twentiethcentury evangelicalism. Studies of missionaries, from Katharine Gerbner's work on eighteenthcentury Moravians and slavery to David Hollinger's study of how missionary children transformed twentieth-century American scholarship, and studies of the ways in which American conservatives continue to rally supporters on the basis of their religious commitments, such as Bethany Moreton's prize-winning study To Serve God and Wal-mart, make clear the reasons why we cannot understand what people do unless we examine the reasons they themselves offer. 
The scope of American intellectual history will continue to extend from low to high, from concrete practices to abstract doctrines, and, as it always has, beyond the nation's borders. Since the eighteenth century scholars have studied American thought in relation to its European roots. That tradition persists in multiple forms. Studies of emigré intellectuals, from James Wilson and Tom Paine to Hannah Arendt and Leo Strauss, and of Americans transformed by travel, from Benjamin Franklin, Thomas Jefferson, and William James to W. E. B. DuBois, Josephine Baker, and James Baldwin, continue to proliferate. ${ }^{17}$ The scope is widening, with studies that link Americans to the Middle East, Russia, South Asia, and Africa further complicating understandings of American writers' "native ground." Such extensions of American intellectual history will themselves be embedded now that the "spatial turn" has alerted historians to the need to integrate geography into their studies of the past. ${ }^{18}$

Moreover, these transnational intellectual histories no longer concentrate on the books written by Americans about the glorious experience of being freed from Yankee provincialism or of the books shipped home from abroad that shaped Americans' ways of thinking. As part of his expansive study of the vexed relation between the American civil rights movement and the anticaste and anti-colonial movements in India, Nico Slate not only recounts the multi-directional flow of ideas but also diverse social experiences, including those of American black soldiers in South Asia during World War II, he explains for the first time how and why perceptions of the color line changed as a result of such interactions. ${ }^{19}$

The questions asked and the sources consulted will continue to expand as the global extension of transnational studies continues, yet the long-standard and still most familiar forms of intellectual history, namely the study of philosophy, political and social thought, and the relation between ideas and political and social movements, will surely persist. In $\underline{\text { The }}$ Declaration of Independence: A Global History, David Armitage demonstrated that Jefferson's audience included not only Americans and Britons but, perhaps just as crucially, the rest of the world. If other nations had not been persuaded that the former colonists had a sound basis for 
declaring their independence from Britain, securing that independence would have been even more challenging. And as Armitage showed by expanding his analysis chronologically as well as geographically, Jefferson's words have continued to reverberate in our own day.

Among the most arresting developments of recent years is the flurry of activity surrounding the eighteenth-century history of the Caribbean, specifically the emergence of what Laurent Dubois has called "an enslaved Enlightenment." Although scholars of slavery and antislavery, notably David Brion Davis and Seymour Drescher, have always employed a transnational framework, a new generation of historians is recasting the debate by looking away from Europe. Dubois, Vincent Brown, and Malech Ghachem have discussed the circulation of ideas in Saint Domingue before and after the French Revolution. They have shown how developing ideas of universal rights subverted the system of slavery and the means by which enslaved Africans, by their resistance and eventually through rebellion, themselves made concrete the abstract doctrine of the rights of man. Relying on a wide range of sources from legal documents to planters' warnings to the writings of French scribes after the Haitian Revolution, these scholars are giving new meaning to the idea that the intellectual history of the Atlantic world will become increasingly embodied, embedded, and extended as it expands to encompass the ideas of illiterate slaves who listened, talked, argued, and created their own doctrine of human rights. ${ }^{20}$

New studies of politics and reform in the early republic likewise span the Atlantic. The work of Rachel Hope Cleves, The Reign of Terror in America, and Matthew Rainbow Hale, The French Revolution and the Transformation of American Democracy, demonstrate the shaping influence of the French experience with democracy on the first party system in the US. Margaret Abruzzo's Polemical Pain: Slavery, Cruelty, and the Rise of Humanitarianism shows how British moral philosophy, sentimentalism, and antislavery activism not only framed American abolitionism but also the proslavery arguments that developed in response. 
Transnational topics in the nineteenth and twentieth centuries have continued to attract intellectual historians. Leslie Butler's Critical Americans picked up the challenge issued decades ago in the collection of essays Victorian America and explored the rich connections between late nineteenth-century writers on both sides of the Atlantic who shared commitments to the principle of democracy and dissatisfaction with its contemporary incarnations. My own book Uncertain

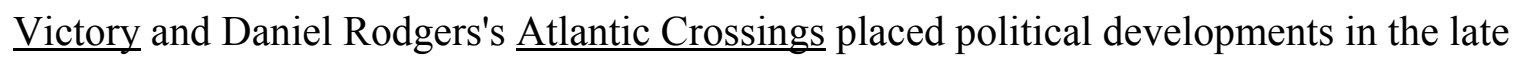
nineteenth and early twentieth centuries in a transatlantic context, showing how and why reform initiatives enjoyed different degrees of success even when they shared common roots. Recent studies of the liberal idea of modernization have used a global framework to show how that concept was deployed in the mid-twentieth century not only in the northern Atlantic but also in Asia and Africa. Histories of the idea of human rights likewise cannot be confined to a single national story. In an age of increasing globalization, transnational studies of ideas may become more the rule than the exception. ${ }^{21}$

Transnational studies of leftist intellectuals will increasingly be joined by studies of conservative thinkers. Angus Burgin's Return of Laissez-Faire uncovers the self-conscious commitment to building a conservative movement undertaken during World War II by European and American intellectuals who breathed life into ideas that many contemporaries considered irretrievably discredited by association with fascism. ${ }^{22}$ If forging the link between academic economics and social theory and the eventual emergence of a renewed American conservatism in the 1970s and 1980s remains one of the most urgent challenges facing American historians, studies like Burgin's will be as indispensable as studies like Moreton's. Understanding conservatives' spirited defense of the free market means following the circuitous path that led from the Alps to the Ozarks, from Mt. Pelerin to Bentonville. Historians must study newsletters and magazines as well as learned treatises, forage in archives of church groups and civic organizations as well as foundations and think tanks, and resist the inclination to see the traffic 
as one-way--in either direction. Will that project involve intellectual, social, cultural, political, religious, or economic history? Emphatically, yes.

Powerful as the transnational turn has been, fertile fields remain within the United States, notably in the study of western and southern intellectual history. When the nation's population and its leading universities were clustered in the North and the Midwest regions, intellectual historians' concentration on those regions made some sense. De-provincializing American intellectual history requires not only attention to the cultures of Europe, Asia, Africa, and the Caribbean. It also demands further efforts to explore long-understudied regions within the borders of the United States. ${ }^{23}$

Intellectual history will also continue to extend beyond the boundaries of our discipline. Blessed with instant electronic access to scholarly journals in fields such as literature, political theory, philosophy, law, medicine, public policy, science studies, the behavioral sciences, and critical theory, intellectual historians can effortlessly track developments in neighboring scholarly fields. To cite just a few obvious examples, journals such as American Literary

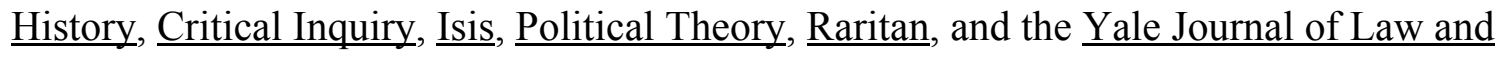
Humanities often publish work that could just as easily appear in Modern Intellectual History. As scholars increasingly escape disciplinary silos and address topics wielding tools drawn from other parts of the academy, they are moving toward the extended eclecticism characteristic of intellectual history. Conceived as a cultural practice, intellectual history is thriving in many disciplinary homes.

New advances in technology will further enliven and complicate the historical study of ideas. With more and more texts digitally searchable, we will no longer estimate how often particular names or words or formulations appeared in the historical record. Computer-assisted analyses of texts will grow increasingly sophisticated. The complexity of grammar and word choice in individual texts can already be measured; the next frontier includes the ability to discern ironic understatement and parody. IBM's computer "Watson" can beat humans at the 
game of Jeopardy; will its descendants outperform our best graduate students in oral examinations and evaluate the work of future undergraduate history majors?

Such developments make many intellectual historians uneasy. Computers process words at a pace no human can match. As translation programs improve, machines will work through quantities and varieties of texts that even the most relentless and multi-lingual researcher cannot match. But such anxieties are misplaced. No matter now much raw data textual analysis can provide, the interpretation of such data will remain a project for humans, not machines. Even now, the most sophisticated textual analysis is only as good as the people who design the protocols. Humans must decide what to count and how to analyze the data that computers retrieve. Machines cannot know, on their own, what to do with the information they generate. Hearing the echoes of Rousseau in James Wilson's speeches, even though Wilson never used the phrase "general will"; recognizing the stamp of Aristotle and Hegel in Dewey's writings, even though Dewey abandoned Aristotelian and Hegelian terminology; and discerning the similarities and differences among the ideas of Judith Sargent Murray, Sarah Grimke, Charlotte Perkins Gilman, and Betty Friedan will remain challenges that only discerning historians will be able to meet.

Exciting--or mind-numbing--new arenas for interpretation will emerge. The Library of Congress has begun cataloging and preserving the data contained in blogs. Given the nearly limitless options for analyzing that limitless information, computer analysis will prove indispensable. But the central question of coding will remain. There is no alternative to critical judgment in determining how to proceed once everything originally printed and everything digitally produced can be subjected to quantitative analysis. What criteria will determine the questions to be asked? We now realize that all of our analytical categories are constructions, tools that reflect conventions instead of resting on something fundamental or transhistorical. Can the critical insights that generated our suspicion of the "given" be translated into adequately nuanced criteria for searching in digital sources? 
Will increasing reliance on computer-assisted textual analysis will lead to a redefinition of historical studies? If quantitative analysis of the Evans imprints or the files of the New York Times leads us to ask only questions beginning with "what" or "how often" instead of "why," something precious will be lost. If cognitive science and evolutionary psychology yield a new positivist reductionism that leads its enthusiasts to see all forms of cultural expression as biological adaptations to changing stimuli, then questions of interpretation may seem epiphenomenal and intellectual historians will be out of business. But we need not be alarmed. Studies of the brain are demonstrating the inescapability of hermeneutics: at the most fundamental level, the brain must interpret the meaning of its perceptions of sense data. ${ }^{24}$ Anxieties about scientism only echo the fears prompted by the earlier waves of sociobiology and quantitative analysis that have crested periodically since the 1870s. Questions of meaning and consciousness will recur. ${ }^{25}$

The basis on which historians make critical judgments has traditionally developed from sustained and intensive as well as wide-ranging study. There is still no substitute for learning how to wrestle historical meanings from a single text, whether it is a sermon by Roger Williams or Henry Ward Beecher or Jim Wallis; a journal entry recorded by Martha Ballard or Margaret Fuller or Margaret Mead; a speech delivered by Frederick Douglass or Jane Addams or Malcolm X; or a letter written by Mercy Otis Warren or Alice James or C. Vann Woodward. Interpretation is inevitably a value-laden critical practice. Although unprecedentedly vast quantities of information will no doubt enrich historians' evidentiary base, that information will never completely answer our questions about what past experiences and expressions meant to those we study and what that evidence should mean to us. Intellectual historians in the twenty-first century will be concerned, as they have always been, with balancing the most insightful and best informed judgments about the meanings of texts in the past against the most discerning critical judgment about the needs of the present. 
Technological advances we can barely imagine will surely alter the tools future intellectual historians will use. But historical studies of ideas will continue to be embodied in persons; culturally embedded in various social practices and the institutional sites in which meanings are produced, disseminated, and received; and extended ever further, not only from low to high but across national and cultural boundaries and into vast storehouses of data only now becoming digitally accessible. Notwithstanding all of those changes, historians' goals will remain the same: not only gathering information but understanding the past on its own terms, and, equally important, interpreting its significance for the present.

As intellectual historians produce embodied, embedded, and extended studies in the future, they will view historical evidence from different perspectives and for different purposes. For that reason, just as we situate those we study in their own contexts, we historians should see ourselves as embodied, embedded, and extended among a range of wider and deeper contexts. We should view ourselves reflexively and situate our practice self-consciously in our own historical circumstances. Intellectual historians have only particular, not universal, perspectives and purposes. Those perspectives and purposes inevitably inform and enrich our distinctive form of creative action, the production of new historical interpretations for our own cultural moment.

\section{Notes}

1.David A. Hollinger, In the American Province: Studies in the History and Historiography of Ideas (Bloomington, 1985), p. 177.

2.A sample of prize-winning intellectual biographies published recently includes Alan Brinkley, The Publisher: Henry Luce and His American Century (New York: Knopf, 2010); Charles Capper, Margaret Fuller, An American Romantic, 2 vols. (New York: Oxford University Press, 1992, 2007); Eric Foner, The Fiery Trial: Abraham Lincoln and American Slavery (New York: Norton, 2010); David Levering Lewis, W. E. B. DuBois, 2 vols. (New York: Henry Holt, 1993, 2000); George Marsden, Jonathan Edwards: A Life (New Haven: Yale University Press, 2003); and Megan Marshall, The 
Peabody Sisters: Three Women Who Ignited American Romanticism (New York: Houghton Mifflin, 2005).

3. Quentin Skinner, Visions of Politics, vol. 1, Regarding Method (Cambridge, 2002), p. vii: "If we are to write the history of ideas in a properly historical style, we need to situate the texts we study within such intellectual contexts and frameworks of discourse as enable us to recognise what their authors were doing in writing them."

4. Arthur O. Lovejoy, "Reflections on the History of Ideas," Journal of the History of Ideas 1 (1940): 3-23.

5. On the continuing usefulness of some now less fashionable insights from the linguistic turn, see Gabrielle M. Spiegel, "The Task of the Historian," American Historical Review 114 (2009):115 .

6. Annette Gordon-Reed, The Hemingses of Monticello: An American Family (New York, 2008); Lance Banning, The Sacred Fire of Liberty: James Madison and the Founding of the Federal Republic (Ithaca, 1995); and Trygve Throntveit, Power without Victory: Woodrow Wilson and the American Internationalist Experiment, forthcoming.

7. A few recent examples include The American Indian Intellectual Tradition: An Anthology of Writings from 1772 to 1972, ed. David Martinez (Ithaca, 2011); Maureen Konkle, Writing Indian Nations: Native Intellectuals and the Politics of Historiography, 18271863 (Chapel Hill: University of North Carolina Press, 2004); Steven Conn, History's Shadow: Native Americans and Historical Consciousness in the Nineteenth Century (Chicago: University of Chicago Press, 2004);Adolph Reed, Jr., and Kenneth W. Warren, eds., Renewing Black Intellectual History: The Ideological and Material Foundations of African American Thought (Boulder, CO, 2010); Rosemaire Zagarri, Revolutionary Backlash: Women and Politics in the Early American Republic (Philadelphia, 2007); Mary Kelley, Learning to stand and Speak: Women, Education, and Public Life in America's Republic (Chapel Hill, 2007); and Caroline Winterer, The Mirror of Antiquity: American Women and the Classical Tradition, 1750-1900 (Ithaca, 2007).

8. Compare Robert Darnton, The Forbidden Best-sellers of Eighteenth-Century France (New York, 1995); Darnton, Poetry and the Police: Communication Networks in Eighteenth-Century Paris (Cambridge, 2010); Roger Chartier, "Do Books Cause Revolutions?" in Chartier, The Cultural Origins of the French Revolution, trans. Lydia G. Cochrane (Durham, NC, 1991), pp. 169-197; and the recent symposium "What Was the History of the Book?" with contributions by Bill Bell, Darnton, Chartier, Peter Burke, and David D. Hall," in Modern Intellectual History 4 (2007): 491-544. 
9. The History of the Book in America, 5 vols., ed. David D. Hall et al. (Chapel Hill, 2007-2009).

10. See The Works of Jonathan Edwards, vol 12, Ecclesiastical Writings, ed. David D. Hall (New Haven, 1994), pp. 80-85.

11. Eric Slauter, "Reading and Radicalization: Print, Politics, and the American Revolution," Early American Studies 8, 1 (2010): 5-40.

12. Jennifer Ratner Rosenhagen, American Nietzsche (Chicago, 2012; see also Martin Woessner, Heidegger in America (Cambridge, 2011); and Caroline Winterer, The Culture of Classicism: Ancient Greece and Rome in American Intellectual Life, 1780-1910

(Baltimore, 2002).

13. See for example Jamie Cohen-Cole, "Cold War Salons, Social Science, and the Cure for Modern Society," Isis 100 (2009): 21962; Staging Growth: Modernization, Development, and the Global Cold War, ed. David C. Engerman, Nils Gilman, et al. (Amherst, 2003); Joel Isaac, Knowledge by Design: Crafting the Human Sciences in Modern America (Cambridge, 2012); Andrew Jewett, To Make America Scientific: Science, Democracy, and the University before the Cold War (Baltimore, 2012); Rebecca Lemov, World as Laboratory: Experiments with Mice, Mazes, and Men (New York, 2006); and cf. Lorraine Daston, "Science Studies and the History of Science," Critical Inquiry 35 (2009): 798-813.

14.See Emma Rothschild's introduction to the Forum "The Idea of Sustainability," with essays by Paul Warde, Alison Frank, and Rothschild," in Modern Intellectual History 8 (2011): 147-151.

15. See for example John Micklethwait and Adrian Wooldridge, The Company: A Short History of a Revolutionary Idea (New York, 2003); and Daniel Belgrad, The Culture of Spontaneity:

Improvisation and the Arts in Postwar America (Chicago, 1998).

16. See James T. Kloppenberg, Tragic Irony: Democracy in European and American Thought (Oxford: Oxford University Press, forthcoming), chapter 8 .

17. See for example Jennifer Burns, Goddess of the Market: Ayn Rand and the American Right (New York, 2009; Francesca Bordogna, William James at the Boundaries: Philosophy, Science, and the 
Geography of Knowledge (Chicago, 2008); and Brook Blower, Becoming Americans in Paris: Transatlantic Politics and Culture between the World Wars (New York, 2011).

18. Charles W. J. Withers, "Place and the 'Spatial Turn' in Geography and in History, Journal of the History of Ideas 70 (October 2009): 637-658.

19. Nico Slate, Colored Cosmopolitans: Race and the shared Struggle for Freedom in the United States and India (Cambridge, MA, 2011). See also Kris Manjapra, "From Imperial to International Horizons: A Hermeneutic Study of Bengali Modernism," Modern Intellectual History 8 (2011): 327-359.

20. See Laurent Dubois, Avengers of the New World: The Story of the Haitian Revolution (Cambridge, MA, 2004); and Dubois, "An Enslaved Enlightenment: Rethinking the Intellectual History of the French Atlantic," Social History 31 (2006): 1-14.

21. Engerman et al., Staging Growth; Elizabeth Borgwardt, $\underline{A}$ New Deal for the World: America's Vision for Human Rights

(Cambridge, MA, 2005); Samuel Moyn, The Last Utopia: Human Rights in History (Cambridge, MA, 2010); and, more broadly Thomas Bender, ed., Rethinking American History in a Global Age

(Berkeley, 2002).

22. Angus Burgin, The Return of Laissez-Faire (Cambridge, 2012).

23. The intellectual history of the West has so far attracted less attention than that of the South. Cf. Donald Worster, $\underline{A}$ Passion for Nature: The Life of John Muir (New York, 2008); Michael O'Brien, Conjectures of Order: Intellectual Life and the American South, 1810-1860, 2 vols. (Chapel Hill, 2004); and Michael Bernath, Confederate Minds: The Struggle for Intellectual Independence in the Civil War South (Chapel Hill, 2010).

24. See Eric Schwitzgebel, Perplexities of Consciousness (Cambridge: MIT Press, 2011).

25. For a recent overview of developments in this domain, ranging from the project Mapping the Republic of Letters to work at the National Center for Supercomputing Applications, see Patricia Cohen, "A New Enlightenment: Digital Keys to the Humanities' 
Riches," The New York Times, November 17, 2010, pp. C1, C5. I am hardly the best guide: after reading Cohen's article in the newspaper, I clipped it and put it in a manila folder. The future lies with those whose folders are all electronic. 